\author{
N.V. Chekaleva ${ }^{1}$, Z.K. Kulsharipova ${ }^{2 *}$, L.S. Syrymbetova ${ }^{2}$, B.A. Matayev $^{3}$, D.E. Omarova ${ }^{2}$

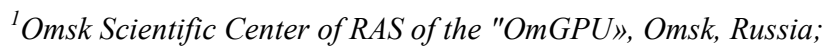 \\ ${ }^{2}$ Pavlodar State Pedagogical University Pavlodar, Pavlodar, Republic of Kazakhstan; \\ ${ }^{3}$ Eurasian National University named after L.N. Gumilyov, Nur-Sultan, Kazakhstan \\ (Corresponding author's e-mai: kulsharipovazk@mail.ru) \\ ORCID 0000-0001-6170-099X ${ }^{l}$
}

\title{
Comprehensive support of children with autistic spectrum disorders
}

\begin{abstract}
Today, autism is a significant social problem that is becoming more widespread, affecting children who have the same type of developmental problems, but with different options for overcoming them. This is what causes the idea of autism as a set of autism spectrum disorders. Children with ASD are a polymorphic group, which manifests itself in psychological and pedagogical features, which complicates social adaptation. In psychological and pedagogical terms, children with ASD are allocated to a special group, since interaction is built differently due to qualitative communication disorders. In many cases, children with ASD who come to school have unformed learning behaviors. For the successful development of the program material in children with ASD, it is necessary to form a stereotype of educational behavior, on which all school education is based. Deficits in the formation of these skills can lead to a longer period of adaptation of the child in school and to difficulties in mastering the program. In this article, we consider the necessary skills, the formation of which is aimed at psychological and pedagogical assistance to a child with ASD in preparation for school.
\end{abstract}

Keywords: psychological and pedagogical support, affective pathology, emotional and intellectual experience, correctional impact, children with autism spectrum disorders, social and household adaptation.

\section{Introduction}

The current state of education is characterized by an intensive search for the most effective forms of educational activity, the creation of such conditions of learning and development that would contribute to the maximum disclosure of the child's personality.

Today, the requirements of society for the development of the personality of children, including children with autism spectrum disorders, dictate the need for a more complete analysis, development and implementation of individual educational programs as differentiated assistance to children aimed at overcoming difficulties in communication and social interaction, successful adaptation and integration into the children's community. Autism in a broad sense is usually understood as a clear lack of communication, the desire to get away from contacts, to live in their own world [1].

The book by E.R. Baenskaya examines the early stages and patterns of emotional development. The most significant signs of affective trouble for early diagnosis are described, their combinations characteristic of the distortion of emotional development are highlighted. The logic is traced formation of different variants of early childhood autism, specific problems are determined [2].

Comprehensive support of school-age children with ASD is understood as a system of professional activity of psychologists, focused on creating the most favorable psychological and pedagogical conditions for adaptation in the school community, based on effective interaction. It starts in with the diagnosis of the child's capabilities, further building remedial work with children with ASD as a technique of unobtrusive assistance and create conditions for the manifestation of the potential of the pupil in the program of psychological and pedagogical support.

\section{Literature review}

The development of social relations depends on the socio-cultural characteristics of the environment. In adolescents, difficulty thinking outside of formal operations turns into an inability to adequately analyze their thoughts and feelings, which leads to inhibition of reflection. At the same time, the teenager's attitude to the world and to himself changes significantly (A. Vallon, L.I. Bozhovich, A.M. Prikhozhan). Suicidal behavior is defined as intentional self-harm or actions of this kind that have negative consequences for a person. Most often, this concept refers to auto-destructive and self-injurious behavior (Van der Kolk, Perry, Herman, 1991), verbal auto-aggression (Cohen et al.,2020). 
In the analytical theory of C.G. Jung, this process has a positive meaning, aimed at development. The extreme form of self - destructive behavior-suicide-is considered here as an attempt to rise to a new level of development and spiritual rebirth [3]. From the point of view of A. Adler, such motives in the development of personality suggest an «inferiority complex». It appears in early childhood, and a person spends his whole life looking for ways to overcome it. If a teenager faces an insurmountable obstacle in this search, it can lead to a crisis.

But teachers should understand that a crisis situation (or crisis «solution, turning point, outcome» from Greek) can be defined in the most General way as «a transition period, revolution, turning point in a transition state».

In pedagogical psychology, this concept was introduced by L.S. Vygotsky. He identified the stable and critical stages of ontogenesis that separate one stable period from another. A feature of the crisis period is the manifestation of regression, difficulties in the child's learning, in relationships with others, and in such periods the development is significantly accelerated: «Development is taking rapid, sometimes catastrophic, it reminds revolutionary course of events as the pace of change and meaning change» [4].

\section{Main part (methods)}

The program includes an individual route of the child's development, which contributes to the child's entry into the educational process not only within the school system, but also outside it.

The organization of psychological and pedagogical support of a child with ASD in the program goes through next stages:

- diagnostic (identification of the problem, diagnostic analysis, identification of participants in psychological and pedagogical assistance, establishing contact with the parents (legal representatives) of the child);

- search (collective search for possible solutions to the problem, informing all members of the group);

- consultative-projective (selection of the joint optimal direction of work, determination of the duties of the psychologist for its implementation, forecasting of effectiveness);

- activity-based (implementation of the selected plan, achievement of the required result).

In our research, we have developed a program that consists of 2 modules. Module 1-Explanatory note. Module 2-recommendations for children and teachers, parents.

The main goal of the program is to help a child with ASD adapt to the conditions of kindergarten. The program consists of the following areas:

1. Overcoming affective pathology, establishing contact and gaining trust and developing rules for working in the office.

1.1 During the first meetings of the child with the teacher-psychologist, it is necessary to give him the opportunity to study the office.

1.2 If possible, soundproof the room. Communication with the child should be conducted in a low voice, if possible, avoid looking directly at the child, so that he does not experience discomfort.

1.3 Clothing should be chosen in low-key tones, and there should be constancy in it, so that it is easier for the child to get used to the specialist.

The basic educational program of primary general education of children with ASD consists of two parts:

- a mandatory part;

- the part formed by the participants of educational relations.

The structure of the approximate variable educational program of children with ASD includes:

1. Explanatory note, which reveals: the goals and objectives of the special educational needs (SEN) educational needs, the timing of the development of the educational program, psychological and pedagogical characteristics of students (requirements for the development of students).

2. Principles and approaches to the formation of a program of correctional work carried out with students with ASD in inclusive education (option A), as well as requirements for the results and conditions of its implementation.

3. The planned results of the development of students ' options for the adapted basic educational program of primary general education $(\mathrm{B}, \mathrm{C}$ and $\mathrm{D})$.

4. A system for evaluating the achievement of planned learning outcomes by students.

5. The content of education:

- Program for the formation of basic training activities;

- The program of correctional work; 
- Extracurricular activities program;

- The curriculum, including the calendar schedule of the organization of the educational process

Programs include the study of:

- to study the child in more detail, to involve them in joint activities through the enrichment of their emotional and intellectual experience.

- identification of stimuli that can serve as a positive reinforcement in the child's learning: correctional work should include art therapy, finger games, sand and water work. The main objectives of the program when working with children with ASD are:

1. Creating an adequately organized environment, which becomes the main method of corrective action when working with a child.

2. Developing the child's understanding of time. For children with ASD, «marking» time is very important.

3. Structuring of all types of activities.

4. Overcoming unevenness in the development.

5. The organization of the communicative mode of communication.

6. Support of the educational process.

7. Social and household adaptation.

ASD is a fairly common problem of childhood and is characterized by impaired development of communication tools and social skills. Common are affective problems and difficulties in developing active relationships with a dynamically changing environment, the attitude to maintaining constancy in the environment and stereotypical behavior of children. ASD is associated with a special systemic disorder of the child's mental development, which manifests itself in the formation of his affective-volitional sphere, in cognitive and personal development. Autism will become an increasingly significant social problem affecting a wide variety of children.

In this regard, now they are talking not only about childhood autism, but also about a wide range of autism spectrum disorders. The origin of ASD affects the nature and dynamics of a child's mental development disorder, determines the associated difficulties, and affects the prognosis of social development.

\section{Discussion}

Thus, due to the extreme heterogeneity of the composition of children with ASD, the range of differences in the required level and content of their primary school education should be as wide as possible, corresponding to the capabilities and needs of all such children: to include both an education comparable in level and time of mastering with the education of normally developing peers, and the possibility of special (correctional) education throughout primary school age. It is important to emphasize that in order to receive primary education in a mass program in an inclusive environment (option A), the most well-off children with ASD need special support to ensure that their special educational needs are met $[5,6]$.

A differentiated approach to the construction of the content of the thematic plan for students with ASD involves taking into account their special educational needs, which are manifested in the heterogeneity of opportunities for mastering the content of education.

The presented thematic plan provides conditions for general cultural and personal development based on the formation of basic educational activities that ensure not only the successful assimilation of certain elements of the system of scientific knowledge, skills and abilities (academic results), but also, above all, life competence, which is the basis of social success (table 1).

$\mathrm{Table} 1$

The thematic plan

\begin{tabular}{|c|l|c|}
\hline № & \multicolumn{1}{|c|}{ The theme } & Hours \\
\hline \hline 1 & \multicolumn{1}{|c|}{2} & 3 \\
\hline 1. & Makes an eye contact & 1 \\
\hline 2. & Simulates basic movements & 1 \\
\hline 3. & Simulates actions with objects & 1 \\
\hline 4. & Simulates small and precise movements & 1 \\
\hline 5. & The imitation of pronouncing movements & 1 \\
\hline 6. & The implementation of individual teams & \\
\hline
\end{tabular}


N.V. Chekaleva, Z.K. Kulsharipova et al.

\begin{tabular}{|c|c|c|}
\hline 1 & 2 & 3 \\
\hline 7. & Body part & 1 \\
\hline 8. & Items & 1 \\
\hline 9. & Pictures & 1 \\
\hline 10. & Recognition of familiar people & 1 \\
\hline 11. & Verbs (Commands and actions in pictures) & 1 \\
\hline 12. & The surrounding objects & 1 \\
\hline 13. & Points to the pictures in the book & 1 \\
\hline 14. & Item assignments & 1 \\
\hline 15. & affiliation & 1 \\
\hline 16. & Finds out ambient sounds & 1 \\
\hline 17. & Indicates the desired items & 1 \\
\hline 18. & Names the desired items verbally & 1 \\
\hline 19. & yes/no (preference and disrespect) & 1 \\
\hline 20. & Calls familiar people & 1 \\
\hline 21. & Makes a choice & 1 \\
\hline 22. & Social issues & 1 \\
\hline 23. & Verbs & 1 \\
\hline 24. & Matches & 1 \\
\hline 25. & Colors & 1 \\
\hline 26. & shapes and shapes & 1 \\
\hline 27. & The letters & 1 \\
\hline 28. & Numbers & 1 \\
\hline 29. & Simulates standing movements & 1 \\
\hline 30. & Simulates movements in a sequence & 1 \\
\hline 31. & Simulates actions paired with sound & 1 \\
\hline 32. & Repeats the construction with cubes & 1 \\
\hline 33. & Copies simple drawings & 1 \\
\hline \multirow[t]{2}{*}{34.} & Rooms & 1 \\
\hline & Subtotal & 34 \\
\hline
\end{tabular}

A significant part of children with ASD is available and shows a censored education, which is correlated by the level of the «academic» component with the education of healthy peers, received in a joint learning environment with them in the same calendar terms.

Inclusion is most appropriate for children with ASD who have a formally comparable level of psychoverbal development (we focus on groups 3 and 4, according to the Russian psychological classification of autistic children), and is optimal if the child has experience of preparing for it in a group of children before entering school [7].

An inclusive environment provides an opportunity for a child with an autism spectrum disorder to increase the level of social interaction and therefore improve their skills, interaction with peers gives a child with autism a chance to practice communication skills, make friends and observe how peers behave in everyday situations.

The basic principles of forming a program of correctional work with students with ASD are as follows (table 2):

Table 2

\section{Basic principles of formation of the program of correctional work}

\begin{tabular}{|l|l|l|}
\hline \multicolumn{1}{|c|}{ The principle of } & \multicolumn{1}{|c|}{ The situation } & \multicolumn{1}{c|}{ The action } \\
\hline $\begin{array}{l}\text { gradual, individually dosed } \\
\text { communication }\end{array}$ & $\begin{array}{l}\text { in the classroom situation: starting with the } \\
\text { lessons of }\end{array}$ & $\begin{array}{l}\text { he feels most comfortable and } \\
\text { successful, until full inclusion; }\end{array}$ \\
\hline $\begin{array}{l}\text { development of social and everyday } \\
\text { skills and communication skills with }\end{array}$ & $\begin{array}{l}\text { problems related to, orientation in the ongo- } \\
\text { ing }\end{array}$ & $\begin{array}{l}\text { the dosed and temporary help of } \\
\text { the tutor should be connected to }\end{array}$ \\
\hline $\begin{array}{l}\text { difficulties in the formation of educa- } \\
\text { tional behavior in an included child } \\
\text { with ASD }\end{array}$ & $\begin{array}{l}\text { development of forms of adequate educa- } \\
\text { tional behavior, the ability to enter into } \\
\text { communication and be regulated in interac- } \\
\text { tion with the teacher }\end{array}$ & $\begin{array}{l}\text { Adequately perceive praise and } \\
\text { comments }\end{array}$ \\
\hline
\end{tabular}


The main tasks of psychological and pedagogical support are: formation of readiness of a child with ASD to join a group of peers; formation of mutual understanding of parents of children with ASD and parents of normatively developing peers; formation of mutual adaptation of children in a group of peers.

In this regard, the main tasks of psychological and pedagogical support and the introduction of a correctional program with special modules and training topics contribute to the formation of ideas about the world around us;

- the development of the ability to comprehend, organize and differentiate individual life experiences;

- the development of self-awareness based on the study of memories, ideas about the future;

- the development of the ability to plan, choose, compare, and comprehend cause-and-effect relationships in what is happening.

The need for special assistance in learning and understanding children with ASD assimilated the lessons is the mechanical accumulation of experience verbal communication, opportunities to engage in dialogue, to share their thoughts, experiences, feelings.

Create a learning environment provides the setting, sensory and emotional comfort (no sharp mood swings, smooth and warm tone of voice of the teacher in relation to any class), so consistency and predictability of what is happening. In these conditions, it is necessary to give a special instruction to teachers to develop emotional contact with the child, maintain confidence in him that he is accepted, sympathized with, that he is successful in the classroom; broadcast this instruction to fellow students of the child with ASD, emphasizing his strengths [8].

The demonstration of sympathy for him through his attitude in real behavior in the learning process should be supported by psychological support that optimizes the interaction of the child with teachers and fellow students, the family and the school in the child's primary school. Step-by-step psychological and pedagogical support of children is also carried out in classes that include elements of fairy-tale therapy and game therapy. In the classroom, children are introduced to the characteristics of a child with ASD. An individual program of support for a child with ASD involves the selection of optimal methods and forms of work with the child when preparing and including him in a group of peers. At the initial stages, the work is aimed at mitigating the general background of sensory and emotional discomfort, stimulating mental activity in interaction with adults and peers, forming purposeful behavior, overcoming negative forms of behavior.

\section{Result}

The program describes possible methods of working with a child with ASD: the method of sensory integration, educational kinesiology, art-therapeutic methods and methods of applied behavior analysis.

The target group in our conditions of post-rehabilitation psychological and pedagogical support consisted of: teachers who carry out the educational program of a child with ASD, children with autism spectrum disorders of school age, parents or legal representatives of children with ASD, preschool children who are participants in the inclusive space, parents of standard typical children. The conditions necessary to meet the special educational needs of children with ASD include (table 3):

Ta b le 3

\section{Conditions for meeting the special educational needs of children with ASD}

\begin{tabular}{|l|l|}
\hline \multicolumn{1}{|c|}{ Conditions meet the SED } & \multicolumn{1}{|c|}{ Content there } \\
\hline $\begin{array}{l}\text { Implementation of targeted correctional work in the pro- } \\
\text { cess of learning by children }\end{array}$ & $\begin{array}{l}\text { is a development of the content of educational areas, there } \\
\text { is an understanding of the environment }\end{array}$ \\
\hline $\begin{array}{l}\text { Organization of support of the educational process of stu- } \\
\text { dents }\end{array}$ & ensures the mastery of students ' life competencies \\
\hline $\begin{array}{l}\text { Organization of support for a family raising a child with } \\
\text { autism spectrum disorde }\end{array}$ & is the basis of social success \\
\hline
\end{tabular}

The program of post-rehabilitation psychological and pedagogical support for a school-age child with autism spectrum disorder provides training and support for school teachers and this process is carried out in several stages: 
1. The primary information stage includes obtaining information about a child who has been admitted to preschool: from parents, from the conclusions of specialists who interact with the child earlier.

2. Stage of diagnosis and definition of the zone of proximal development of the child include: the study of peculiarities of emotional-volitional sphere, personality development, scope and nature of the knowledge and skills correlated with the age and individual characteristics of the child. The diagnostic results allow us to determine the content of education and the conditions for organizing training and build an individual educational route.

3. The activity stage (the stage of «professional support») includes the implementation of planned corrective measures carried out by teachers.

4. The reflexive stage involves intermediate and final diagnostics and monitoring of the effectiveness of the actions taken.

These stages allow you to successfully work with the parent of children and implement the tasks of working with parents.

In the course of the work, a subject-based game environment is organized, which involves taking into account the formation of mutual understanding between parents of children with ASD and parents of standard typical peers.

A full-fledged development environment for such children will be created by mutual and planned efforts of parents and teachers. Specialists conduct a preparatory conversation. Sample questions for the conversation: does your child know that he has autism? etc. Together with the teacher, the parent draws up an information note about the characteristics and preferences of their child. The parent needs to rely on specific points, for example: in what does your child look like ordinary children? Parents are invited to watch the video presentation «5 reasons why a child needs «another society»«. In parallel with the work with the parent of a child with ASD, the program prescribes a number of measures of psychological and pedagogical support for parents of ordinary children.

\section{Conclusion}

For maximum interest in the problem of autism and to understand the nature of a child with ASD, specialists include items of a comprehensive program: a test questionnaire on the topic of parents' awareness of ASD; questions about autism, answers to which parents would like to receive; additional facts and resources that will help to learn more about the characteristics of a child with ASD.

The joint work of the parent of a child with ASD and the parents of other children helps to create close partnerships and achieve the main goal — to create conditions adapted for the child with ASD.

The implementation of a comprehensive correctional program for accompanying children with ASD should take place in the unity of regular, extracurricular activities, in the joint pedagogical work of the educational organization, the family and other institutions of society.

The program of formation of ecological culture, healthy and safe lifestyle is an integral part of the adapted educational program and should be designed in accordance with its other components: planned results, the program of formation of basic educational actions, programs of individual academic subjects, extracurricular activities, moral development.

\section{References}

1 Никольская О.С. Аутичный ребенок. Пути помощи / О.С. Никольская, Е.Р. Баенская, М.М. Либлинг. - М.: Теревинф, 1997.

2 Баенская Е.Р. Помощь в воспитании детей с особым эмоциональным развитием (ранний возраст) / Е.Р. Баенская. М.: Теревинф, 2009.

3 Cohen I.L. et al. A large scale study of the psychometric characteristics of the IBR modified overt aggression scale: Findings and evidence for increased self-destructive behaviors in adult females with autism spectrum disorder, 2009. DOI: 10.1007/s10803009-0908-z.

4 Выготский Л.С. Педагогическая психология [Электронный ресурс] / Л.С. Выготский. — M.: AST, 2009. - Режим доступа: https://www.labirint.ru/books/197299/.

5 Программа для детей раннего возраста (от рождения до трех лет) с аутистическими нарушениями. НМУ «Национальный институт образования», 2010. [Электронный ресурc]. — Режим доступа: https://obuchalka-dlya-detey.ru/wpcontent/uploads/2017/02/100-programm.pdf.

6 Розитта Зюмалла. Обучение и сопровождение детей с аутизмом по программе ТЕАССН [Электронный ресурс] / Зюмалла Розитта, пер. с нем. А. Ладисов, О. Игольников. - Минск: ОО «Белорусская ассоциация помощи детяминвалидам и молодым инвалидам», 2005. — Режим доступа: http://pedlib.ru/Books/6/0042/6_0042-35.shtml. 
7 Кутепов М.М. Возможности здоровьесберегающих технологий в формировании здорового образа жизни / М.М. Кутепов, О.И. Игоревна, А.В. Трутанова // Балт. гум. журн. - 2017, 6 (3 (20). - С. 210-213. - Режим доступа: https:/cyberleninka.ru/article/n/vozmozhnosti-zdoroviesberegayuschih-tehnologiy-v-formirovanii-zdorovogo-obraza-zhizni.

8 Васягина Н.Н. Психолого-педагогические аспекты реабилитации детей с расстройством аутистического спектра в условиях дошкольного образования [Электронный ресурс] / Н.Н. Васягина, Е.Н. Григорян, Е.А. Казаева // Нац. психол. журн. - 2018. - (2 (30). - С. 92-101. - Режим доступа: https://cyberleninka.ru/article/n/psihologo-pedagogicheskie-aspektyreabilitatsii-detey-s-rasstroystvom-autisticheskogo-spektra-v-usloviyah-doshkolnogo-obrazovaniya.

\title{
Н.В. Чекалева, З.К. Кульшарипова, Л.С. Сырымбетова, Б.А. Матаев, Д.Е. Омарова
}

\section{Аутистік спектр аурулары бар балаларды кешенді сүйемелдеу}

\begin{abstract}
Бүгінгі таңда аутизм - бұл бір типтегі даму проблемалары бар, бірақ оларды жеңудің әр түрлі нұсқалары бар балаларға әсер ететін үлкен әлеуметтік проблема. Бұл аутизм идеясын аутизм спектрінің бұзылуының жиынтығы ретінде анықтайды. АСБ бар балалар — бұл әлеуметтік бейімделуді қиындататын психологиялық-педагогикалық ерекшеліктерде көрінетін полиморфты топ. Психологиялық-педагогикалық тұрғыдан алғанда, АСБ бар балалар арнайы топқа бөлінеді, өйткені қарым-қатынас сапалы коммуникацияның бұзылуына байланысты басқаша құрылады. Көптеген жағдайларда мектепке келген АСБ бар балаларда оку мінез-құлқы қалыптаспайды. Осы балаларға бағдарламалық материалды сәтті игеру үшін барлық мектеп оқулары негізделетін оқу мінез-құлқының стереотипін қалыптастыру қажет. Бұл дағдыларды қалыптастырудағы жетіспеушілік баланың мектепке бейімделуінің ұзақ кезеңіне және бағдарламаны игерудегі қиындықтарға әкелуі мүмкін. Мақалада мектепке дайындық кезінде АСБ бар балаға психологиялық-педагогикалық көмек көрсетуге бағытталған қажетті дағдылар қарастырылған.
\end{abstract}

Кілт сөздер: психологиялық-педагогикалық сүйемелдеу, аффективті патология, эмоционалдық және зияткерлік тәжірибе, түзету әсері, аутистік спектрдің бұзылулары бар балалар, әлеуметтік-тұрмыстық бейімдеу.

\section{Н.В. Чекалева, 3.К. Кульшарипова, Л.С. Сырымбетова, Б.А. Матаев, Д.Е. Омарова}

\section{Комплексное сопровождение детей с расстройствами аутистического спектра}

\begin{abstract}
Сегодня аутизм - это широко распространенная и важная социальная проблема, которая затрагивает детей с одинаковыми проблемами развития, но с разными вариантами их преодоления в процессе обучения. Это то, что объясняет концепцию аутизма как набора расстройств аутистического спектра. Дети с расстройствами аутистического спектра (РАC) представляют собой полиморфную группу, которая отражается на их психоло-педагогической характеристике, что затрудняет социальную адаптацию. В психолого-педагогическом отношении дети с РАС выделены в особую группу, поскольку взаимодействие строится иначе в связи с нарушениями коммуникации. Во многих случаях у пришедших в школу детей с РАС оказывается несформированным стереотип учебного поведения. Для успешного освоения программного материала у детей с РАС необходимо формировать учебные стереотипы, на основании которых строится школьное обучение. Дефицит в формировании самых необходимых навыков может привести к более длительному периоду адаптации ребенка к школе и к трудностям в усвоении программ. В статье рассмотрена проблема разработки программ психологопедагогической помощи ребенку с РАС при включении в процесс школьного обучения.
\end{abstract}

Ключевые слова: психолого-педагогическое сопровождение, аффективная патология, эмоциональный и интеллектуальный опыт, коррекционное воздействие, дети с расстройствами аутистического спектра, социально-бытовая адаптация.

\section{References}

1 Nikolskaya, O.S., Baenskaya, E.R., \& Libling, M.M. (1997). Autichnyi rebenok. Puti pomoshchi [An autistic child. Ways of help]. Moscow: Terevinf [in Russian].

2 Baenskaya, E.R. (2009). Pomoshch v vospitanii detei s osobym emotsionalnym razvitiem - rannii vozrast [Help in the upbringing of children with special emotional development (early age)]. Moscow: Terevinf [in Russian].

3 Cohen, I.L. et al. A large scale study of the psychometric characteristics of the IBR modified overt aggression scale: Findings and evidence for increased self-destructive behaviors in adult females with autism spectrum disorder DOI: 10.1007/s10803-0090908-z.

4 Vigotskii, L.S. (2008). Pedahohicheskaia psiholohiia [Educational psychology]. Publ. AST. labirint.ru. Retrieved from https://www.labirint.ru/books/197299/ [in Russian]. 
5 Prohramma dlia detei ranneho vozrasta (ot rozhdeniia do trekh let) s autisticheskimi narusheniiami. (2010). NMU «Natsionalnyi institut obrazovaniia» [Program for young children (from birth to three years) with autistic disorders. NMU «National Institute of Education»]. obuchalka-dlya-detey.ru. Retrieved from https://obuchalka-dlya-detey.ru/wp-content/uploads/2017/02/100programm.pdf [in Russian].

6 Rozitta, Zyumalla (2005). Obuchenie i soprovozhdenie detei s autizmom po prohmme TEASSN. (A. Ladisov, O. Igolnikov, Trans). Minsk. Obshchestvennoe obedinenie «Belorusskaia assotsiatsiia pomoshchi detiam-invalidam i molodym invalidam» [The program «Support for autistic and retarded children. A collection of exercises for professionals and parents on the TEACH program»]. pedlib.ru. http://pedlib.ru/Books/6/0042/6_0042-35.shtml [in Russian].

7 Kutepov, M.M., Vaganova, O.I., \& Trutanova, A.V. (2017). Vozmozhnosti zdorovesberehaiushchikh tekhnolohii v formirovanii zdorovoho obraza zhizni. [The possibilities of health-saving technologies in the formation of healthy lifestyle]. Baltiiskii humanitarnyi zhurnal - Baltic Journal ofg Humanities, $6(3$ (20)), 210-213. Retrieved from https://cyberleninka.ru/article/n/vozmozhnosti-zdoroviesberegayuschih-tehnologiy-v-formirovanii-zdorovogo-obraza-zhizni [in Russian].

8 Vasyagina, N.N., Grigoryan, E.N., \& Kazaeva, E.A. (2018). Psiholoho-pedahohicheskie aspekty reabilitatsii detei $\mathrm{s}$ rasstroistvom autisticheskoho spektra $\mathrm{v}$ usloviiakh doshkolnoho obrazovaniia [Psychological and pedagogical aspects of rehabilitation of children with autism spectrum dicorder in preschool education]. Natsionalnyi psiholohicheskii zhurnal - National psychological journal, (2 (30)), 92-101. Retrieved from: https://cyberleninka.ru/article/n/psihologo-pedagogicheskie-aspekty-reabilitatsiidetey-s-rasstroystvom-autisticheskogo-spektra-v-usloviyah-doshkolnogo-obrazovaniya [in Russian]. 